\title{
Capital Market Performance as a Panacea for Economic Growth in Nigeria
}

\author{
Akpokerere Othuke Emmanuel $^{1}$, Okoroyibo Eloho Elizabeth ${ }^{2}$ \\ ${ }^{1}$ Lecturer, Department of Banking and Finance, Delta State Polytechnic Ozoro, Delta State, Nigeria \\ ${ }^{2}$ Lecturer, Department of Accountancy, Delta State Polytechnic Ozoro, Delta State, Nigeria \\ Correspondence: Akpokerere Othuke Emmanuel, Lecturer, Department of Banking and Finance, Delta State \\ Polytechnic Ozoro, Delta State, Nigeria.
}

Received: October 11, 2019

Accepted: December 5, 2019

Online Published: December 20, 2019

doi:10.5539/ibr.v13n2p1

URL: https://doi.org/10.5539/ibr.v13n2p1

\begin{abstract}
The paper examined capital market performance as a panacea for economic growth in Nigeria from 1986-2016. A number of related literatures have shown that the Nigerian capital market variables studied has satisfactory market performance and has contributed to economic growth. Yet some researchers observed that the capital market has not significantly mobilized and effectively channeled substantial capital to the real sector of the economy. What could have been the reason for the divergences? The study was anchored on the demand following hypothesis. Secondary data were sourced from Central Bank of Nigeria Statistical Bulletin and Nigeria Stock Exchange fact-book of various editions. The paper adopted the ex-post facto research design while ordinary least square regression techniques was used to process the data gathered using E-views 9.0 software. The null hypotheses (Ho) were tested at 5\% level of significance. The findings of the paper revealed that there is negative and insignificant relationship between capital market and the variables studied. The paper conclude that liquidity of the capital market is pivotal for economic growth in Nigeria while the study recommended that all tiers of government should be encouraged to fund their realistic long term developmental program through the Nigeria capital market.
\end{abstract}

Keywords: economic growth, value of stock traded, volume of stock traded

\section{Introduction}

The Nigeria environment is a complex super structure comprising several inter-related sectors and activities that work together to facilitate economic growth. The real sector of the economy is essentially involved in the production of goods and services. It activities cut across agriculture, manufacturing, mining, quarrying, water resources, service and technology, environment and tourism. This sector has the highest potential for achieving a broad based and diversified economy, but its performance has been unimpressive over the years. (Edo \& Erovie, 2016).

However, the impressive or unimpressive of all other sectors performance hinges on the soundness of the financial sector. In a nutshell, the financial sector is the heartbeat of any economy, and the capital market is a major focal point of the financial sector. The capital market provides a platform where financial resources are pooled and made available to productive ventures (Oke, 2013). According to Donwa and Odia (2010), the capital market has been identified as an institution which contributes to the socio-economic growth and development of emerging and developed economies. This is made possible by the intermediary role played by the capital market in mobilizing funds from surplus units to deficits units to be invested into projects with positive net present value (NPV) which will enhance economic growth of the nation.

The Nigerian economy has experienced mixed fortunes over the years in her quest for sustained economic growth. Between 1986 and 2016 the Nigerian Capital Market has moved from position of trust and dwindling confidence. Moreso, a little over 3.8 million people of over a population of 160 million people of over a population of 160 million people are investors in the market. Thus, the market is better described as small in size (NSE, 2014).

There has been a mixed and divergent position on the capital market and economic growth nexus leading to confusion on appropriate policy stance to spur growth through capital market performance in Nigeria. Some of 
these studies have posted that market indicators such as Value of transactions and Volume of shares traded indicated positive and significant contributions to the economic growth (Odo, Anoke, Onyeisi \& Chukwu, 2017; Obiakor, 2016; Briggs, 2015; Igbodika, 2014); while others observed that the market has not significantly mobilized and effectively channeled substantial capital to the real sector of the economy (Okonkwo, Ogwuru \& Ajudua, 2014; Adewuyi \& Olowookere, 2011). Even at this, contradictions also emanated wherein studies showed that capital market indices promoted economic growth (Jagadish, 2017; Kumar, 2016; Nordin \& Nordin, 2016; Jalloh, 2015; Regmi, 2012; Duca, 2007), and others revealed that the capital market has not positively and significantly affected economic growths of studied economies (Karim \& Chaudhary, 2017; Wang \& Ajit, 2013; Jamil \& Shazia, 2013; Abdul-Khalia, 2013).Given these divergences in the relationship between capital market performance and the economic growth, capital market policies that spur growth may not be focused.

The main objective of the study is to examine capital market performance as a panacea for economic growth in Nigeria: 1986-2016. Specifically, the studied is to ascertain the relationship between values of stock traded ratio and economic growth in Nigeria; to ascertain the relationship between volume of stock traded and economic growth in Nigeria.

In other to achieve the objectives of this study, the following questions were developed: To what extent has value of stock traded ratio interacted with economic growth in Nigeria? To what degree does the relationship between volumes of stock traded relate to economic growth in Nigeria?

This study will be guided by the following hypothetical statements which are stated in the null form;

$\mathrm{Ho}_{1}$ : Economic growth is not a significant function of value of stock traded in Nigeria.

$\mathrm{Ho}_{2}$ : Volume of stock traded does not significantly relate with economic growth in Nigeria.

This paper studied how the Nigerian Capital Market performance relates to economic growth and much attention were not given to evaluating the soundness of the market. Besides the study did not cover all the variables of the capital market performance, only two out of the available ten measurements were considered in the study. The indicators not studied include all share index, market capitalization ratio, total market new issues, market turnover ratio, total listed securities, total number of issues, number of deals and total value of deals.

\section{Review of Related Literature}

\section{Concept of Capital Market and Economic Growth}

The capital market is the segment of the financial market where long-term instruments (generally those with original maturity of more than one year) are created and/or traded to meet the long-term funding needs of economic activities (Ibenta, 2000). The role of the capital market in the economy includes its contribution to speedy economy growth and development through enhancing production and productivity in the national economy. The capital market provides the necessary vehicle required for the mobilization of idle savings for productive activities in the economy (Akpan, 2013).

Economic growth is measured by changes in the gross domestic product; this measures a country's entire economic output for the past year. This takes into account all goods and services that are produced in the country for sale, whether they are sold domestically or sold overseas. It only measures final production, so that the parts manufactured to make a product are not counted. Exports are counted, because they are produced in this country. Imports are subtracted from economic growth (Brown \& Nyeche, 2016).

\section{Theoretical Framework}

This study is anchored on the demand following hypothesis based on its emphasis on the importance of finance in the context of a developing country like Nigeria.

\section{The Demand Following Hypothesis}

The demand-following view states that capital market development follows economic growth (Robinson, 1952). As the economy expands its demand for certain financial instruments increases, leading to the growth of these services (Hugh, 1966; Jung, 1986; Odhiambo, 2010).

Hugh (1966) stated that, the causal nature of relationship between financial development and economic growth has not been fully explored either theoretically or empirically. Moving away from the neo-classical state equilibrium analysis, to a highly developed financial system, consisting of financial intermediaries, leads to a 'demand following' phenomena (Hugh, 1966). Under this, in response to the demand from real economy, there is the creation of modern financial institutions, their financial assets and liabilities, and related financial services. 


\section{Empirical Studies on Value of Stock Traded Ratio and Economic Growth}

Karim and Chaudhary (2017) appraised the effect of stock market development on economic growth of two Asian regions namely South Asia and East Asia. They used market capitalization, total value traded ratio and turnover ratio as indicators of stock market development while gross domestic product per capita growth rate is used for measuring economic growth. The linear panel data methodology is applied over the annual data of 1996-2015 to study the phenomenon. The empirical findings indicate that turnover ratio contributes to some extent in the economic growth of South Asian region but its impact on East Asian region found to be insignificant.

Odo, Anoke, Onyeisi and Chukwu (2017) adopted auto regressive distributed lag bound testing and VAR granger causality econometric tools to estimate the relationship between value of stock traded ratio and economic growth in Nigeria. The result indicated stock traded total value had a negative insignificant link with economic growth in both short and long run.

Abbas, Pei and Rui (2016) explored the relationship between the stock market measures and economic growth in Tanzania. In order to achieve the objective, they examined the impact of stock total value of share traded on Tanzanian economy based on the time series data from 2000 - 2011. They employed the Ordinary Least Square techniques and their findings suggest that total value of share traded has no effect on economic growth of Tanzania.

\section{Empirical Studies on Volume of Stock Traded and Economic Growth}

Spaseska, Vitanova, Sotiroski, Odzaklieska, Jankuloska and Risteska (2017) examined the extent which capital market performance influences real sector growth in Macedonian economy. Correlative and regressive analysis of time series disclosed that there is a very strong link between gross domestic product and the performances of the Macedonian stock exchange: market capitalization of the listed companies, volume of trading on the Macedonian stock exchange and number of listed companies in Malaysia and United Kingdom.

Werema and Nikupala (2016) investigated the impact of stock exchange market to the economic growth in Tanzania over a period of 1998 - 1992. A simple regression model using the 1998-2012 annual data sets was employed. The empirical findings show that volume of transaction has significant and positive impact on economic growth.

Oladokun, Adeagbo and Abiola (2015) assessed the impact of Nigerian Stock Market on the country's economic growth between 1981 and 2013 using Wald test analysis and ordinary least square techniques. The economic growth was proxy by gross domestic product while various stock market variables such as market capitalization, total new issues, volume of transaction and total listed equities and government stock were considered. It was revealed that volume of transaction has positive and significant relationship with economic growth.

\section{Methodology}

This study adopts the ex-post facto research design. The events being examined have already taken place providing already established secondary data for the study. The data for the study were collected from source that the researchers has no ethical and statutory powers to manipulate. Hence, the data were collected and used in their original state.

\section{Description of Variables in the Models}

Economic growth is the dependent variable and was proxied by Real Gross Domestic Product Growth Rate (RGDPGR) which measures the changes in real output. The explanatory variables which are the indices of capital market performance include Value of Stock Traded Ratio (VSTTR) and Volume of Stock Traded (VOLSTR). The RGDPGR as stated above is real gross domestic product growth rate. This is the change in real gross domestic product. This adjustment transforms the money-value measure, nominal Gross Domestic Product into an index for quantity of total output measured in millions of Naira. Echekoba and Ananwude (2016) while following Chizea (2012), stated that RGDPGR captures the actual change in GDP from the previous year to the current and, thus, if the economy has grown it is positive and, if it has not, then it will be negative. Echekoba, Ezu and Egbunike (2013) and Echekoba and Ananwude (2016) used this indicator in their study.

VSTTRA is value of stock traded ratio: This is the total value of shares traded during the period deflected. This indicator complements the market capitalization ratio by showing whether market size is matched by trading. It is expected that an increase in value of transactions will spur economic growth in an economy. This indicator was used in the works of Echekoba and Ananwude (2016), Adigwe, Nwanna and Ananwude (2015) and Enisan and Olufisayo (2009). 
VOLSTRD is volume of stock traded: This refers to the volume of stocks traded over a specified period of time on the floor of the Nigerian Stock Exchange. A higher volume suggests more trading is taking place on the exchange. This variable was employed in the works of Obubu, Konwe, Nwabenu, Omokri and Chijioke (2016), Owolabi and Ajayi (2013), Oke and Adeusi (2012), and Ewah, Esang and Bassey (2009).

\section{Model Specification}

The model of analysis follows a linear combination of explanatory tune series variables. The paper adopted and modified the model of Edame and Okoro (2013) for a similar study in Nigeria. Edame and Okoro (2013) expressed economic growth as a function of capital market performance fundamentals visa viz: market capitalization, number of deals, value of transaction and interest rate. The original model is stated as:

$$
\mathrm{GDP}_{\mathrm{t}}=\beta_{0}+\beta_{1} \text { MAKAP }_{\mathrm{t}}+\beta_{2} \mathrm{NDEALS}_{\mathrm{t}}+\mathrm{VTRAN}_{\mathrm{t}}+\beta_{4} I N T_{t}+\varepsilon_{t} \ldots \ldots \ldots \ldots \ldots
$$

To determine specifically capital market performance as a panacea for economic growth in Nigeria, the following model was develop.

$$
\begin{gathered}
\text { RGDPGRt }=\beta_{0}+\beta_{1} \operatorname{logVSTTRAt}+\beta_{2} \log \text { VOLSTRDt }+\varepsilon_{t} \quad \ldots \ldots . \\
\text { Where: }
\end{gathered}
$$

The variables are as explained under variables description above,

RGDPGRt $=$ the gross domestic product real growth rate in year $\mathrm{t}$

$\beta_{1}$ to $\beta_{2}$ are beta coefficients of the explanatory variables

$\beta_{0}=$ the constant/intercept of the model.

$\varepsilon_{\mathrm{t}}=$ error term

\section{Methods of Data Analysis}

In the course of carrying out the data analysis in this study the following procedures and methods are employed:Unit Root Test - to ascertain stationarity of the data to avoid the incidence of spurious regression. This was done using the Augmented Dickey-Fuller and Phillips Perron approaches at level (trend and intercept) and first differencing (also trend and intercept) respectively. After confirming stationarity of all the data and the order integration, a co-integration test was carried out for evidence any long run relationship among the variables utilizing the Johansen approach. Decision to adopt vector error correction model or vector auto-regressive model is based on the outcomes of the co-integration and unit root tests. The statistical package employed for the analysis is E-views 9.

\section{Data Presentation}

The data were sourced from Central Bank of Nigeria statistical bulletins and Nigeria Stock Exchange factbook of various issues.

\section{Real Gross Domestic Product Growth Rate}

Real gross domestic product growth rate of Nigeria was 1.86 in 1986, but rose by $78.65 \%$ by the end of 2010 to settle at 8.71 . From 2005 to 2008 , there was a marginal rise in real gross domestic product growth rate from 6.55 in 2005 to 6.72 in 2008 before it declined to 5.04 in 2011. From 2012 to 2016, as shown in Fig. 1 and 2, real gross domestic product growth rate has been depreciating. In 2016, the economy witnessed a negative growth as the real gross domestic product growth rate was -1.52 due to recession that engulfed the economy at that period.

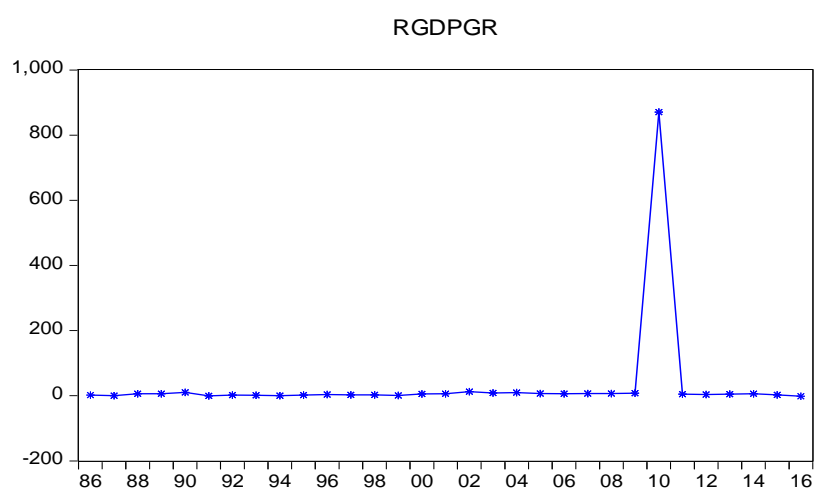

Figure 1. Graphical Trend in Real Gross Domestic Product Growth Rate 1986 to 2016 
Source: Central Bank of Nigeria Annual Report, 1986 - 2016; and output data from e-views 9.0 version.

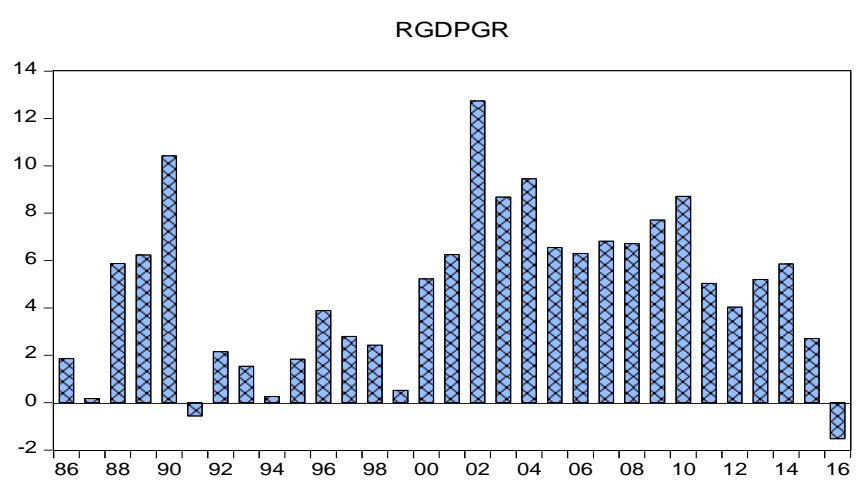

Figure 2. Bar Chart Trend in Real Gross Domestic Product Growth Rate 1986 to 2016

Source: Central Bank of Nigeria Annual Report, 1986 - 2016; and output data from e-views 9.0 version. VSTTR

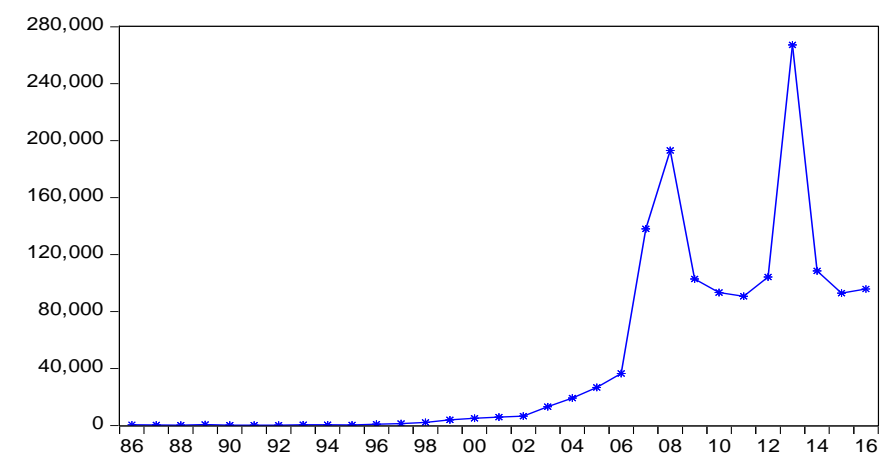

Figure 3. Graphical Trend in Value of Stock Traded Ratio 1986 to 2016

Source: Nigerian Stock Exchange factbook, 1986 - 2016; and output data from e-views 9.0 version.

\section{Value of Stock Traded Ratio}

The value of stock traded ratio was $0.45 \%$ in 1986 , which had risen by $95.50 \%$ by 2010 to settle at $10.0 \%$. The value of stock traded ratio greatly fluctuated from 2010 to 2016 , declining to just $1.0 \%$ in 2016 compared to $10.0 \%$ in 2009. From 2001 to 2016, as shown in Table 2, Fig. 3 and 4, value of stock traded ratio magnificently depreciated from $26.22 \%$ in 2001 to $1.0 \%$ in 2016.

VSTTR

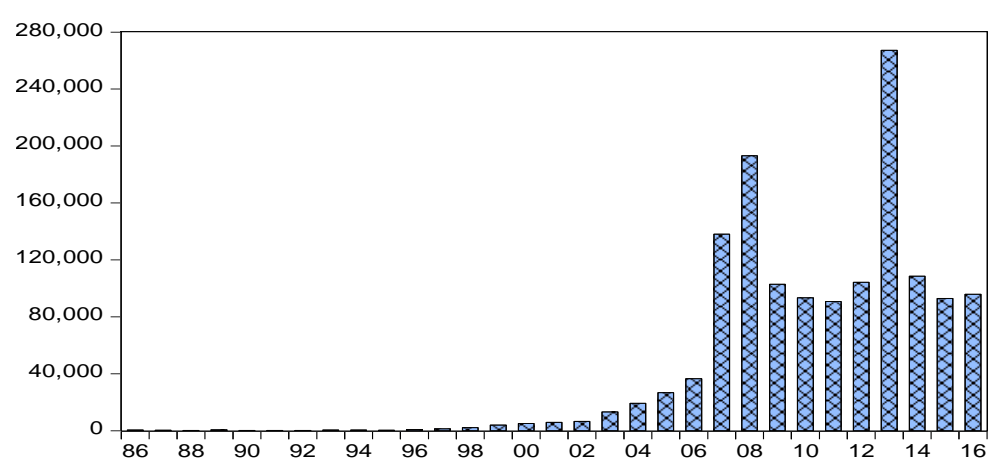

Figure 4. Bar Chart Trend in Value of Stock Traded Ratio 1986 to 2016

Source: Nigerian Stock Exchange factbook, 1986 - 2016; and output data from e-views 9.0 version.

\section{Volume of Stock Traded}

In 1986 the volume of stock traded was $\$ 495.99$ billion but it rose to $\$ 93,300$ billion in 2010, envisaging over $99.47 \%$ appreciation volume of stock traded. The volume of stock traded significantly increased to $\$ 193,140$ 
billion in 2008 from $\$ 6,600$ billion in 2002 . With inferences from Table 2, Fig. 5 and 6, volume of stock traded rose from $\$ 5,900$ billion in 2001 to $\$ 95,814.79$ billion in 2016.

VSTR

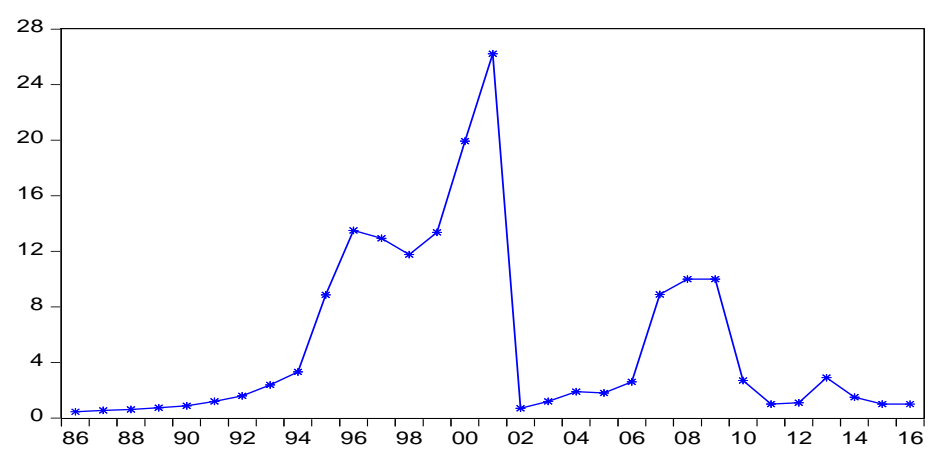

Figure 5. Graphical Trend in Volume of Stock Traded 1986 to 2016

Source: Nigerian Stock Exchange factbook, 1986 - 2016; and output data from e-views 9.0 version.

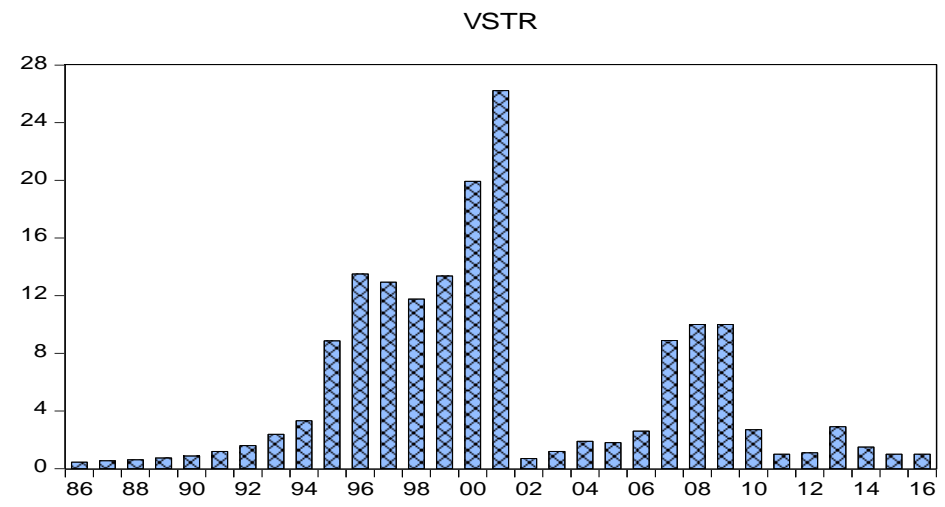

Figure 6. Bar Chart Trend in Volume of Stock Traded 1986 to 2016

Source: Nigerian Stock Exchange factbook, 1986 - 2016; and output data from E-views 9.0 version.

Table 1.1. Descriptive Statistics of the Variables of the Study

Date:
10/07/19 Time:
20:33
Sample: 19862016

\begin{tabular}{lccc}
\hline & RGDPGR & VSTTRA & VOLSTRD \\
\hline Mean & 4.802000 & 5.538333 & 8.851803 \\
Median & 5.215000 & 2.140000 & 8.738767 \\
Maximum & 12.74000 & 26.22000 & 12.49613 \\
Minimum & -1.520000 & 0.540000 & 5.176150 \\
Std. Dev. & 3.453278 & 6.563854 & 2.487781 \\
Skewness & 0.139290 & 1.522744 & -0.050816 \\
Kurtosis & 2.501841 & 4.719612 & 1.459301 \\
& & & \\
Jarque-Bera & 0.407211 & 15.29007 & 2.980104 \\
Probability & 0.815784 & 0.000478 & 0.225361 \\
& & & \\
Sum & 144.0600 & 166.1500 & 265.5541 \\
Sum Sq. Dev. & 345.8287 & 1249.441 & 179.4826 \\
Observations & & & \\
\hline
\end{tabular}

Source E-views Output, 2018 


\section{Variables Descriptive Properties}

Table 1.1 reveals the descriptive properties of the variables. The descriptive properties of the variables were highlighted based on the mean, median, maximum, minimum, standard deviation, skewness, kurtosis, Jarque-Bera, p-value and number of observation. From Table 1, the mean of variables are 4.802, 12.128, 8.871, 10.797, 5.538, 6.320 and 8.851for RGDPGR, VSTTRA, and VOLSTRD while their respective median is observed to be 5.215, $2.14,8.738$. The maximum and minimum values are $12.740 \&-1.520,26.220 \& 0.540,12.496 \& 5.176$ also for RGDPGR, VSTTRA, and VOLSTRD respectively. All the variables are positively skewed toward normality.

\section{Diagnostic Tests}

\section{Stationarity Test Result}

The variables were subjected to stationarity test to ensure the data are not encumbered by the stationarity defect that affects most time series which lead to bias inferences of regression results. Unit root test was checked using Augmented Dickey-Fuller (ADF) and Phillips Perron (PP). The ADF and PP were tested in level and at first difference trend and intercept respectively. The tests show that all the variables are stationary at first differencing (trend and intercept) and are summarized in Tables.

Table 1.2. ADF Test Result at Level: Trend and Intercept

\begin{tabular}{llccc}
\hline Variables & ADF Test Statistic & $\begin{array}{c}\text { Test } \\
\text { Critical Value } \\
\text { at 1\% }\end{array}$ & $\begin{array}{c}\text { Test } \\
\text { Critical Value } \\
\text { at 5\% }\end{array}$ & Remarks \\
\hline RGDPGR & $-2.552321(0.30)$ & -4.296729 & -3.568379 & Not Stationary \\
VSTTR & $-3.139968(0.12)$ & -4.416345 & -3.622033 & Not Stationary \\
VSTR & $-2.429792(0.35)$ & -4.296729 & -3.568379 & Not Stationary \\
\hline
\end{tabular}

Source: Output Data via E-views 9.0

Note: The optimal lag for ADF test is selected based on the Akaike Info Criteria (AIC), p-values are in parentheses where $(*)$ and $(* *)$ denotes significance at $1 \%$ and $5 \%$ respectively

Table 1.3. ADF Test Result at First Difference: Trend and Intercept

\begin{tabular}{llccc}
\hline Variables & ADF Test Statistic & $\begin{array}{l}\text { Test Critical } \\
\text { Value at 1\% }\end{array}$ & $\begin{array}{l}\text { Test Critical } \\
\text { Value at 5\% }\end{array}$ & Remarks \\
\hline RGDPGR & $-4.029045(0.01)^{*}$ & -4.339330 & -3.587527 & Stationary \\
VSTTR & $-9.179407(0.00)^{*}$ & -3.724070 & -2.986225 & Stationary \\
VSTR & $-5.583199(0.00)^{*}$ & -4.309824 & -3.574244 & Stationary \\
\hline
\end{tabular}

Source: Output Data via E-views 9.0

Note: The optimal lag for ADF test is selected based on the Akaike Info Criteria (AIC), p-values are in parentheses where $(*)$ and $(* *)$ denotes significance at $1 \%$ and $5 \%$ respectively.

Table 1.4. Phillips-Perron Test Result at Level: Trend and Intercept

\begin{tabular}{lcccl}
\hline \multicolumn{1}{c}{ Variables } & PPTest Statistic & $\begin{array}{c}\text { Test Critical } \\
\text { Value at 1\% }\end{array}$ & $\begin{array}{l}\text { Test Critical } \\
\text { Value at 5\% }\end{array}$ & Remarks \\
\hline RGDPGR & $-2.552321(0.30)$ & -4.296729 & -3.568379 & Not Stationary \\
VSTTR & $-3.139968(0.12)$ & -4.416345 & -3.622033 & Not Stationary \\
VSTR & $-2.429792(0.35)$ & -4.296729 & -3.568379 & Not Stationary \\
\hline
\end{tabular}

Source: Output Data via E-views 9.0

Note: In determining the truncation lag for PP test, the spectral estimation method selected is Bartlett kernel and Newey-West method for Bandwidth, p-values are in parentheses where $(*)$ and $(* *)$ denotes significance at $1 \%$ and $5 \%$ respectively.

Table 1.5. The Phillips-Perrons Test Result at First Difference: Trend and Intercept

\begin{tabular}{lcccl}
\hline \multicolumn{1}{c}{ Variables } & PP Test Statistic & $\begin{array}{l}\text { Test Critical } \\
\text { Value at 1\% }\end{array}$ & $\begin{array}{l}\text { Test Critical } \\
\text { Value at 5\% }\end{array}$ & Remarks \\
\hline RGDPGR & $-4.029045(0.01)^{*}$ & -4.339330 & -3.587527 & Stationary \\
VSTTR & $-9.414586(0.00)^{*}$ & -2.660720 & -1.955020 & Stationary \\
VSTR & $-5.583199(0.00)^{*}$ & -4.309824 & -3.574244 & Stationary \\
\hline
\end{tabular}

Source: Output Data via E-views 9.0 
Note: In determining the truncation lag for PP test, the spectral estimation method selected is Bartlett kernel and Newey-West method for Bandwidth, p-values are in parentheses where $(*)$ and $(* *)$ denotes significance at $1 \%$ and $5 \%$ respectively.

Table 1.6. Cointeregration Test

\begin{tabular}{|c|c|c|c|c|}
\hline \multicolumn{5}{|c|}{$\begin{array}{l}\text { Date: } 10 / 07 / 19 \text { Time: 21:08 } \\
\text { aple (adjusted): } 19882016 \\
\text { Included observations: } 29 \text { after adjustments } \\
\text { Trend assumption: Linear deterministic trend } \\
\text { Series: RGDPGR MKTCAPRAT ALSIND } \\
\text { Lags interval (in first differences): } 1 \text { to } 1\end{array}$} \\
\hline \multicolumn{5}{|c|}{ Unrestricted Cointegration Rank Test (Trace) } \\
\hline $\begin{array}{l}\text { Hypothesized } \\
\text { No. of CE(s) }\end{array}$ & Eigenvalue & $\begin{array}{c}\text { Trace } \\
\text { Statistic }\end{array}$ & $\begin{array}{c}0.05 \\
\text { Critical Value }\end{array}$ & Prob.** \\
\hline $\begin{array}{l}\text { None } * \\
\text { At most } 1 * \\
\text { At most } 2 *\end{array}$ & $\begin{array}{l}0.890505 \\
0.783290 \\
0.694292 \\
\end{array}$ & $\begin{array}{l}193.3921 \\
129.2477 \\
84.90100\end{array}$ & $\begin{array}{l}125.6154 \\
95.75366 \\
69.81889 \\
\end{array}$ & $\begin{array}{l}0.0000 \\
0.0000 \\
0.0020\end{array}$ \\
\hline \multicolumn{5}{|c|}{$\begin{array}{l}\text { Trace test indicates } 4 \text { cointegrating eqn(s) at the } 0.05 \text { level } \\
* \text { denotes rejection of the hypothesis at the } 0.05 \text { level } \\
* * \text { MacKinnon-Haug-Michelis (1999) p-values }\end{array}$} \\
\hline \multicolumn{5}{|c|}{ Unrestricted Cointegration Rank Test (Maximum Eigenvalue) } \\
\hline $\begin{array}{l}\text { Hypothesized } \\
\text { No. of CE(s) }\end{array}$ & Eigenvalue & $\begin{array}{c}\text { Max-Eigen } \\
\text { Statistic } \\
\end{array}$ & $\begin{array}{c}0.05 \\
\text { Critical Value } \\
\end{array}$ & Prob.** \\
\hline $\begin{array}{l}\text { None } * \\
\text { At most } 1 * \\
\text { At most } 2 *\end{array}$ & $\begin{array}{l}0.890505 \\
0.783290 \\
0.694292 \\
\end{array}$ & $\begin{array}{l}64.14441 \\
44.34666 \\
34.36858 \\
\end{array}$ & $\begin{array}{l}46.23142 \\
40.07757 \\
33.87687 \\
\end{array}$ & $\begin{array}{l}0.0003 \\
0.0156 \\
0.0437\end{array}$ \\
\hline $\begin{array}{l}\text { Max-eigenvalue } \\
* \text { denotes reject } \\
* * \text { MacKinnon- }\end{array}$ & $\begin{array}{l}\text { est indicates } 3 \\
\text { n of the hypotl } \\
\text { ug-Michelis ( }\end{array}$ & $\begin{array}{l}\text { grating eqn } \\
\text { t the } 0.05 \text { les } \\
\text { p-values }\end{array}$ & e 0.05 level & \\
\hline
\end{tabular}

Source: E-views 9.0 output 2018

Table 1.6 shows that long-run relationship (co-integration) exists among the variables. This is based on the trace and maximum eigenvalues against the 5\%critical value. Based on these values, it is confirmed that there are three (3) cointegrating equations in the model. In view of the presence of long-run relationship (co-integration) among the variables, it became necessary for Vector Error Correction Model to be adopted for the analysis of the data of the Study in order to capture the short run disequillibrum that might have occurred in estimating the long run cointegrating equations. The outcomes of the vector error correction analysis are displayed on Table 1.7 below. 
Table 1.7. Vector Error Correction Model Results-Gauss-Newton / Marquardt steps

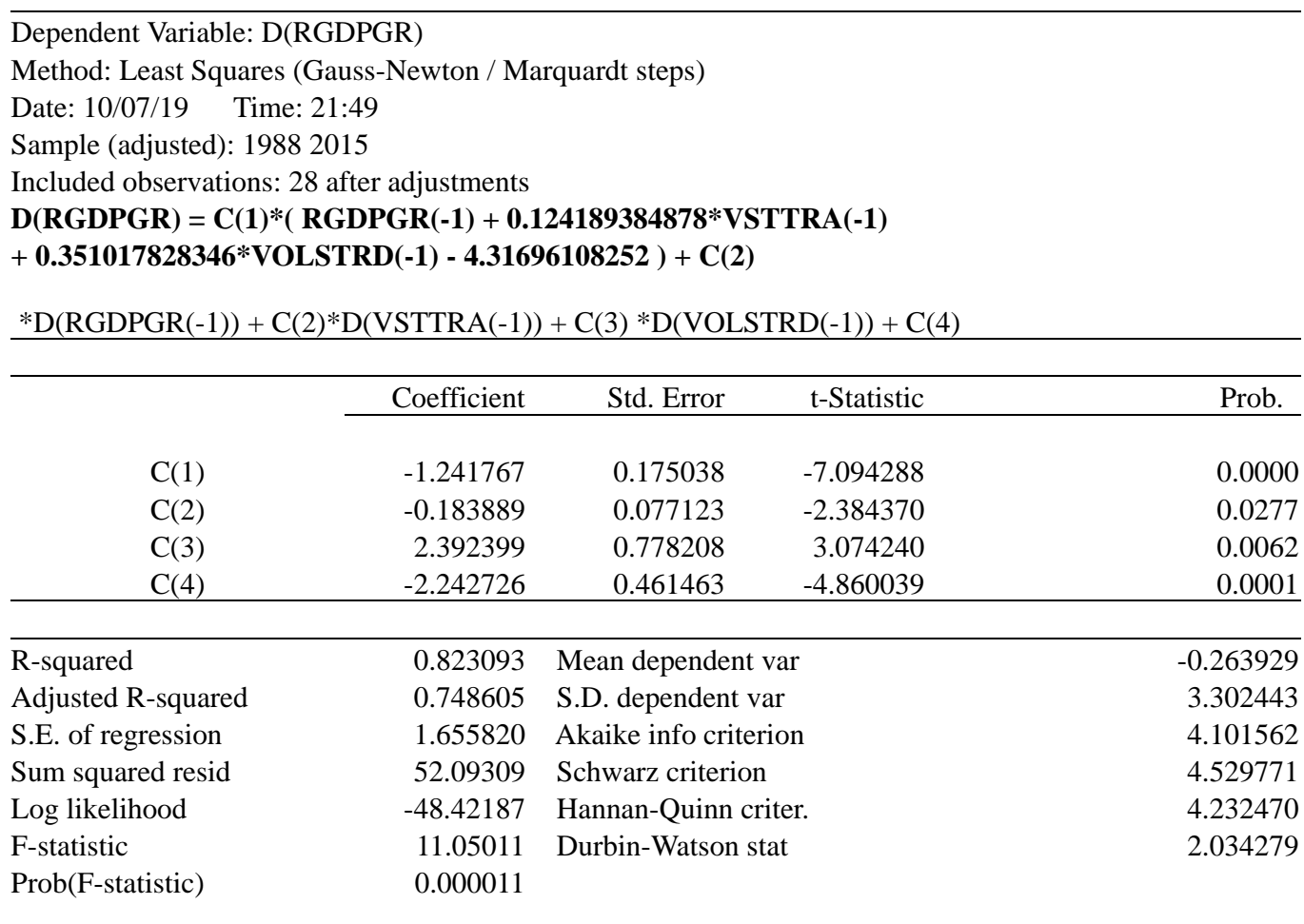

\section{Presentation and Analysis of Results}

From Tables 1.7 above Volume of stock traded- VOLSTRD has a positive but insignificant relationship with the economy with t-value of 0.8 . Value of stock traded- VSTTRA indicate a negative and insignificant relationship. The F-statistic indicates that the model is well fit for the estimation because the associated p-value of 0.0000 at 5 percent significance level. The Durbin Watson Statistic value of 2.03 does not suggest presence of auto correlation. Therefore the model could be used for statistical inference like hypothesis testing.

\section{Test of Hypothesis}

\section{Hypothesis One}

\section{Restatement of Research Hypothesis}

$\mathrm{H}_{0}$ : Economic growth is not a function of value of stock traded in Nigeria.

From the size of the values of the coefficient (-0.124189) and standard error of Value of Stock Traded Ratio VSTTRA on Table 1.8 below; VSTTRA has negative and insignificant relationship with economic growth in Nigeria. Thus the null hypothesis is accepted.

Table 1.8. Coefficient, Standard Error and t-values of Value of Stock Traded

\section{Hypothesis Two}

\begin{tabular}{|c|c|}
\hline $\operatorname{VSTTRA}(-1)$ & -0.124189 \\
\hline & $(0.03148)$ \\
\hline & {$[-3.94463]$} \\
\hline
\end{tabular}

\section{Restatement of Research Hypothesis}

$\mathrm{H}_{0}$ : Volume of Stock Traded does not significantly relate with economic growth in Nigeria.

From the size of the values of the coefficient (0.351018) and Standard error of Volume of Stock TradedVOLSTRD on Table 1.9 below; VOLSTRD has positive and insignificant relationship with economic growth in Nigeria. Thus the null hypothesis is accepted. 
Table 1.9. Coefficient, Standard Error and t-values of Volume of Stock Traded

\begin{tabular}{|c|c|}
\hline VOLSTRD(-1) & 0.351018 \\
\hline & $(0.43407)$ \\
\hline & {$[0.80867]$} \\
\hline
\end{tabular}

\section{Discussion of Findings}

There is negative and insignificant relationship between value of stock traded ratio and economic growth the result is consistent with the studies of Karim and Chaudhary (2017), Odo, Anoke, Onyeisi and Chukwu (2017), Abbas, Pei and Rui (2016), while the studies of Brown and Nyeche (2016), Shao-Chi (2001), Omoniyi, Adeleke and Sikiru (2014), Mwambene (2013) and Dey and Flaherty (2009) found a significant relationship between value of stock traded ratio and economic growth.

Volume of stock traded has a positive and insignificant relationship with economic growth which disagrees with the previous studies of Spaseska, Vitanova, Sotiroski, Odzaklieska, Jankuloska and Risteska (2017), Werema and Nikupala (2016), Oladokun, Adeagbo and Abiola (2015), June (2014) and Sa'adu (2014) while the study of Donwa and Odia (2010) refutes this finding.

\section{Summary of Findings, Conclusion and Recommendations Summary of Findings}

This research paper ascertained capital market performance as a panacea for economic growth in Nigeria, by specifically ascertaining the relationship of value of stock traded ratio and volume of stock traded ratio on economic growth from 1986 to 2016. The findings of the study revealed the following:

1. Value of stock traded ratio has negative and insignificant relationship with Nigeria economic growth for the period under study.

2. There is negative and insignificant relationship between volume of stock traded ratio and Nigeria economic growth for the period under review.

\section{Conclusion}

The paper conclude that since the variables studies has negative and insignificant relationship with economic growth, liquidity of the capital market is pivotal for economic growth in Nigeria. Hence, the capital market remain one of the mainstream in every economy that has the power to influence economy growth, therefore the organized private sector are encourage to invest in the Nigerian capital market.

\section{Recommendations of the study}

Based on the findings, this study puts forward the following recommendations for attention and consideration of decision makers to improve the contribution of the capital market to economic growth in Nigeria:

1. All tiers of government should be encouraged to fund their realistic long term developmental programs through the Nigerian Capital Market. This will served as a lead way to freeing resources that may be used in other sphere of the economy.

2. Capital market regulatory authorities should be more proactive in their surveillance role by promoting preference for stock statements through public enlightenment campaigns, quick payment of dividend to shareholders via automated process and ensure the capital market operators should be more disciplined, acting professionally toward prospective investors so as to increase volume of transactions in the market as this will result in economic growth in Nigeria.

\section{References}

Abbas, A. O., Pei, Y. X., \& Rui, Z. (2016). Impact of stock market on economic growth evidence: Dar-es Salaam Stock Exchange - Tanzania. Journal of Finance and Accounting, 4(6), 321-327. https://doi.org/10.11648/j.jfa.20160406.12

Abdul-Khaliq, S. (2013). The impact of stock market liquidity on economic growth in Jordan. European Journal of Business and Management, 5(30), 154-158.

Adewuyi, I. D., \& Olowookere, J. K. (2011). The contribution of capital market to economic development of Nigeria. International Journal of Economic Development Research and Investment, 2(1), 18-31.

Adigwe, P. K., Nwanna, I. O., \& Ananwude, A. C. (2015). Stock market development and economic growth in Nigeria: An empirical examination. Journal of Policy and Development Studies, 9(5), 134-154. 
https://doi.org/10.12816/0018251

Akpan, I. T. (2013). The extent of relationship between stock market capitalization and performance on the Nigerian economy. Research Journal of Finance and Accounting, 4(19), 181-187.

Briggs, A. P. (2015). Capital market and economic growth of Nigeria. Research Journal of Finance and Accounting, 6(9), 31-40.

Brown, E. D., \& Nyeche, E. W. (2016). Imperative of stock market on economic growth in Nigeria: The endogenous growth model. Business and Economic Journal, 7(1), 2-5.

Central Bank of Nigeria annual report and statements of account 2013, 2014, 2015 and 2016. Central Bank of Nigeria Publications.

Chizea, J. (2012). Stock market development and economic growth in Nigeria: A time series study for the period 1980-2007 (Doctoral dissertation). North Umbria University.

Dey, M. K., \& Flaherty, S. (2009). Stock exchange liquidity, bank credit, and economic growth. Retrieved from web.econ.ku.dk/fru/conference/Programme/Sunday/.../Dey_2_banktstock-mar05.pdf

Donwa, P., \& Odia, J. (2010). An empirical analysis of the impact of the Nigerian Capital Market on her socio-economic development. Journal of Social Sciences, 24(2), 135. https://doi.org/10.1080/09718923.2010.11892845

Duca, G. (2007). The relationship between the stock market and the economy: Experience from international financial markets. Bank of Valletta Review, 3(6), 1-12.

Echekoba, F. N., \& Ananwude, A. C. (2016). The linkage between the depth of development in Nigerian economy under democratic rule. Arabian Journal of Business and Management Review, 2(9), 52-60.

Echekoba, F. N., Ezu, K. E., \& Egbunike, C. F. (2013). The impact of capital market on the growth of the Nigerian economy under democratic rule. Arabian Journal of Business and Management Review, 2(9), $52-60$.

Edame, G. E., \& Okoro, U. (2013). The impact of capital market on economic growth in Nigeria. Journal of Poverty, Investment and Development, 1(1), 45-56.

Edo, B. C., \& Erovie, P. A. (2016). Financial institutions, instruments and markets. Agbor: Krisbee Publication.

Enisan, A. A., \& Olufisayo, A. O. (2009). Stock market development and economic growth. Evidence from seven Sub-Sahara Africa countries. Journal of Economics and Business, 1(3), 162-171. https://doi.org/10.1016/j.jeconbus.2008.05.001

Ewah, S. O., Esang, A. E., \& Bassey, J. U. (2009). Appraisal of capital market efficiency on economic growth in Nigeria. International Journal of Business and Management, 4(12), 219-225. https://doi.org/10.5539/ijbm.v4n12p219

Hugh, P. (1966). Financial development and economic growth in underdeveloped Countries. Journal of Economic Development and Culture Change, 1(4), 174-189. https://doi.org/10.1086/450153

Igbodika, M. N. (2014). Stock market and economic growth of Nigeria. Journal of Integrated Knowledge, 3(1), 105-117.

Jagadish, P. B. (2017). Stock market development and economic growth in Nepal. Journal of Finance and Economics, 5(4), 164-170.

Jalloh, M. (2015). Does stock market capitalization influences economic growth in Africa? Evidence from panel data. Applied Economics and Finance, 2(1), 91-101. https://doi.org/10.11114/aef.v2i1.641

Jamil, T., \& Shazia, F. (2013). Capital market deepening and economic growth in Bangladesh. Studia Ubb Negotia, 3(2), 21-32.

June, T. W. (2014). The relationship between stock market index, turnover ratio, trading volume and economic growth comparison between Malaysia and United Kingdom. A Thesis Submitted to the Department of Finance, Taylor's University. United Kingdom.

Jung, W. S. (1986). Financial development and economic growth: International evidence. Journal of Economic Development and Culture Change, 3(4), 333-346. https://doi.org/10.1086/451531

Karim, S., \& Chaudhary, G. M. (2017). Effect of stock market development on economic growth of major South Asian and East Asian economies: A comparative analysis. Journal of Business Studies Quarterly, 8(3), 
81-88.

Kumar, N. (2016). Estimation of market capitalization and economic growth in India.

Mwambene, T. (2013). Stock market development and economic growth: African emerging market countries and policy implications for Tanzania. A Thesis Submitted to the Department of Economics, KDI School of Public Policy and Management, Tanzania. Retrieved from https://archives.kdischool.ac.kr/bitstream/.../18-Mwambene_Tuntufye\%20-\%2047p.p...

Nordin, S., \& Nordin, N. (2016). The impact of capital market on economic growth: A Malaysian outlook. International Journal of Economics and Financial, 6(7), 259-265.

Obiakor, R. T. (2016). Does capital market development spur economic growth? A look at Africa's largest economy. International Journal of Social Sciences and Humanities Invention, 3(7), 2397-2406. https://doi.org/10.18535/ijsshi/v3i7.05

Obubu, M., Konwe, C. S., Nwabenu, D. C., Omokri P. A., \& Chijioke, M. (2016). Evaluation of the contribution of Nigerian Stock Market on economic growth; Regression approach. European Journal of Statistics and Probability, 4(5), 11-27.

Odhiambo, N. (2010). Finance investment growth nexus in South Africa: An ARDL-bounds testing procedure. Economic Change and Restructuring, 43(3), 205-219. https://doi.org/10.1007/s10644-010-9085-5

Odo, S. I., Anoke, C. I., Onyeisi, O. S., \& Chukwu, B. C. (2017). Capital market indicators and economic growth in Nigeria; An autoregrssive distributed Lag model. Asian Journal of Economics, Business and Accounting, 2(3), 1-16. https://doi.org/10.9734/AJEBA/2017/32549

Oke, M. O., \& Adeusi, S. O. (2012). Impact of capital market reforms on economic growth: The Nigerian experience. Australian Journal of Business and Management Research, 2(2), 20-30.

Okonkwo, O. N., Ogwuru, H. O., \& Ajudua, E. I. (2014). Stock market performance and economic growth in Nigeria: An empirical appraisal. European Journal of Business and Management, 6(26), 33-42.

Okonkwo, V. I., Ananwude, A. C., \& Echekoba, F. N. (2015). Nigeria stock market performance and economic growth in Nigeria: European Journal of Business and Management, 6(26), 33-42.

Oladokun, O. O., Adeagbo, M. A., \& Abiola, B. A. (2015). Wald Test Analysis of the impact of Nigerian Stock Market on economic growth. International Journal of Recent Research in Commerce Economics and Management, 2(3), 106-113.

Omoniyi, B. O, Adeleke, O., \& Sikiru, O. A. (2014). An empirical analysis of the impact of financial market development on the Nigerian economy. Journal of Research in Humanities and Social Science, 2(1), 34-40.

Owolabi, A., \& Ajayi, N. O. (2013). Econometrics analysis of impact of capital market on economic growth in Nigeria. Asian Economic and Financial Review, 3(1), 99-110.

Regmi, U. R. (2012). Stock market development and economic growth: Empirical evidence from Nepal. Administration and Management Review, 24(1), 1-28.

Shao-Chi, C. (2001). Stock market development and economic growth: A panel data approach. Asia Pacific Management Review, 6(3), 357-376.

Spaseska, T., Vitanova, G., Sotiroski, K., Odzaklieska, D., Jankuloska, A. E., \& Risteska, F. (2017). The impact of Macedonian stock exchange performance on economic growth in Republic of Macedonia. Eastern Journal of Social Sciences, 3(3), 131-143.

Wang, B., \& Ajit, D. (2013). Stock Market and Economic Growth in China. Retrieved from https://econpapers.repec.org/RePEc:ebl:ecbull:eb-12-00940

Werema, S., \& Nikupala, L. (2016). Impact of stock exchange market to the economic growth in Tanzania. International Journal of Scientific and Technical Research in Engineering, 1(8), 42-48.

\section{Copyrights}

Copyright for this article is retained by the author(s), with first publication rights granted to the journal.

This is an open-access article distributed under the terms and conditions of the Creative Commons Attribution license (http://creativecommons.org/licenses/by/4.0/). 